\title{
Stock Price Anomalies in Contrast to Stock Performance Predictors - A Comprehensive Study of Cement Industry in Pakistan
}

\author{
Atif Nazir ${ }^{1 *}$, Jahanzaib Alvi ${ }^{2}$, Muhammad Rehan ${ }^{3}$ \\ ${ }^{1}$ Mohammad Ali Jinnah University Karachi, Pakistan \\ ${ }^{2}$ IQRA University Karachi, Pakistan \\ ${ }^{3}$ Ghaziosmanpasa University Tokat, Turkey
}

DOI: $10.36348 /$ sjef.2020.v04i03.004

| Received: 30.12.2019 | Accepted: 06.01.2020 | Published: 21.03.2020

*Corresponding author: Atif Nazir

\section{Abstract}

This research paper has attempted to gauge the relationship amongst dependent and independent variable of firms in Pakistan. Book Value per Share, Earning per Share, Dividend per Share, Gross Domestic Product and Interest Rate are considered as influence factors on movement of Stock Price. For this research 16 organizations are viewed as, recorded in the Pakistan Stock Exchange amid the day and age 2007 to 2016. This exploration will underline on working influences and money related influences and their impact on the gainfulness of the organizations. To gauge the relationship amongst influence and benefit of firms of Pakistan relapse demonstrate and spellbinding measurements will be utilized. Our outcomes will empower the organizations to discover the huge relationship amongst influence and gainfulness of the firm. This study sought to investigate the impact of Book Value per Share, Earning per Share, Dividend per Share, Gross Domestic Product and Interest Rate on Stock Price movement of Pakistan's firm. Importantly there is positive relation between independent variable, i.e. Earning per Share, Dividend per Share \& Interest Rate and dependent variable that is Stock Price.

Keywords: Book Value per Share, Earning per Share, Dividend per Share, Gross Domestic Product, Interest Rate and Stock Price.

Copyright @ 2020: This is an open-access article distributed under the terms of the Creative Commons Attribution license which permits unrestricted use, distribution, and reproduction in any medium for non-commercial use (NonCommercial, or CC-BY-NC) provided the original author and source are credited.

\section{INTRODUCTION}

Factor that actually driving stock market are always considerable area for financial analyst, researchers and investors, before the worldwide monetary emergency of 2007 , the speculation pattern was engaged towards the stock exchange where financial specialists watched out for falling and rising offers as it was a wellspring of yielding noteworthy coming towards speculators. Interest remains having additionally been a wellspring of back for satisfying corporation prerequisites, for example, extension and expansion. It is a by and large acknowledged marvel that financial specialists are hazard opposed and the instability of their speculations cause them extraordinary worry to them as it is a measure of the force of hazard they bear. Be that as it may, from a financial specialist's perspective it is fitting to have information and mindfulness about the determinants of share price with a specific end goal to settle on an ideal speculation choice. Researchers have ascribed a few inner components and outer elements as variables influencing Stock Price [1].

\section{Back Ground of Study}

A considerable measure of research was conducted on the factors and prime mover that impact share prices, the crux of the research may consist on Fundamental analysis, Technical analysis or Investor's behavior (Behavioral Finance). These determinants of share price was started for the developed market likewise US, Europe and others, further it also recognized Dividend Payout, Net Profit Margins (NPM) and Book Value per Share (BVPS) as the conspicuous variables impacting share price in the developed markets, that point onward, a significant assemblage of observational, theoretical and hypothetical and writing has developed that witnessed factors of market price of shares [2].

Securities exchange is a place where optional exchanging of the freely possessed offers and bonds happens. It plays out the part of exchanging of assets from these having surplus wage to those having shortfall wage, so the stock market is assuming part of a mediator or goes amid these two gatherings [3]. 


\section{Sovereign Indicators}

Specialized determinants are the large scale financial factors like Inflation rate in a country, State Bank control on money Supply, Government Monetary Policy for interest rate, a country's GDP Growth, market hype, currency fluctuation, war and climate, exchange rates, industrial production, political occasions, natural disaster and demand and supply and so forth are considerable monetary pointers which can influence Share Price [3].

\section{Fundamental Analysis}

In financial analysis, an analyst always considers entity's own standing by doing fundamental analysis, I more specific fundamental analysis is done by calculating firm's ratio from its own Financial Statements, and give them solid reasoning to reach rationale decision making, hence saying fundamental analysis as ratio wouldn't be un neutral both are same actually. Whereas studies like stock market volatility analyst tend to capture the actual ratio which have significant strong correlation with stock prices, therefore some of ration which more commonly used are Earnings per Share, Book Value per Share, Price Earnings Ratio, Dividend Yield Ratio, and Dividend per Shares, in few of studies development in EPS is the essential explanation behind development in firms dividends payout capacity. Numerous financial specialists focus on organizations' profit prospects when choosing stocks. In this manner, we can express those principal elements, i.e., earning per share (EPS) dividend per share (DPS) impact share prices. Investors always consider when exchanging stocks [4].

\section{Research Problem}

The purpose of choosing this study is to evaluate impact fundamental elements, i.e. Book Value per Share (BVPS), Earnings per Share (EPS) and Dividend per Share (DPS) on share prices of Cement segment. While taking external elements similar to Gross domestic Product and Interest as our control or consistent.

The reaction of previously mentioned subject can be prompt positive or negative effect. It's relying on market and firm condition and investor interest. As financial specialist primary concentration is to pick up benefit.

\section{Justification of Study Gap}

The research will witness experimentally explored determinant of share price development in the Cement sector of Pakistan. This piece of research will be contributing more in context to help rationale investment decision making for investors, good understanding platform for Asset Managers, understanding to Portfolio Managers, sound understanding for newbie in stock market world, and firm policy makers to evaluate their standing in stock market of Pakistan.
For this method of reasoning, the Cement organizations recorded in Stock trades of Pakistan are chosen to identify the connection between fundamental elements, i.e. EPS, DPS and Book Value per Share, and the Stock Price while considering External components, similar to GDP and Interest, consistent.

\section{Research Objective}

The purpose of conducting this research is depends a crucial objectives, these objective probably is to visualize the robust relationship in fundamental and sovereign indicators contrast with share price for specifically in cement industry of Pakistan, as mentioned above as fundamental reflectors we have accounted for DPS, EPS, and BVPS, Sovereign indicators are consists on interest rate and GDP of Pakistan, further finding objectives are mentioned below.

- To find Share Prices significantly influenced by Dividend per Share.

- To find Share Prices significantly influenced by Earnings per Share.

- To find Share Prices significantly influenced by Book Value per Share.

- To find Share Prices significantly influenced by Interest Rate.

- To find Share Prices significantly influenced by Gross Domestic Product.

\section{Research Question}

As mentioned above research objectives below are its driven research questions.

- Is Share Prices significantly influenced by Dividend per Share?

- Is Share Prices significantly influenced by Earnings per Share?

- Is Share Prices significantly influenced by Book Value per Share?

- Is Share Prices significantly influenced by Interest Rate?

- Is Share Prices significantly influenced by Gross Domestic Product?

\section{Limitation of Study}

Only three fundamental factors are considered for research. Second limitation is that effect of factors is only examined on Cement sector of Pakistan. Third and last limitation is that only 10 year data is taken in consideration. Two external factors are considered as control variable in our research.

\section{Key Terms Definitions \\ Earing per Share}

Term earnings per share (EPS) refers proportion of an association's benefit, net of appraisals \& favored stock benefits, that is doled out to individual share of typical stock. The illustration can be registered basically via disengaging net wage earned in a given reporting period (by and large quarterly or yearly) from the total number of offers remarkable in the midst of a 
comparative term. Since the amount of offers excellent can waver, a weighted typical is normally used [5].

\section{Dividend per Share}

Term dividend per share refers to general concepts that how much an investor earn on an individual share of holdings, that further elaborated as firms declares dividend for instant $100 \mathrm{~m}$, and this number will be divided by the number of shares of that firms so that would drive an individual share earnings from cumulative dividend payout.

\section{Book Value Per Share}

In the association per share value available to its fundamental shareholders is obtained by book value per share process. The term "book regard" is association's points of interest short its liabilities and is every so often implied as stockholder's value, proprietor's value, shareholder's value, or basically value. Ordinary stockholder's value, or proprietor's value, can be found on the advantage report for the association. Without favored offers, the total stockholder's value is used.

\section{Gross Domestic Product}

One of the most common estimator which is used to evaluate any country's development that is gross domestic product. GDP refers to a very simple definition "worth of final good and services created by nation in specific time period", hence role of GDP always found significant in context to stock market development in any of the country in the world.

\section{Interest Rate}

Lender charged a fee to borrower who had borrowed money from lender, which is known as Interest. This money can also be used for the purpose of investment in various assets/investments, and then the investor should generate income from the asset in which they invested its money. Interest is the charge for the benefit of acquiring cash, normally communicated as yearly interest rate. Interest can also be said to the amount of ownership a stockholder has in a company, usually expressed as a percentage.

\section{Stock Price}

Market of any share which is being traded in the stock market is called stock price, this trading right is only given to the companies which are listed into stock markets, more generally the worth of any individual share which is being traded into the stock market is called stock price.

\section{Stock Exchange}

Money markets assume an essential part in the financial development of any nation by collecting local assets and guiding them to beneficial speculation. Securities exchange is a place where optional exchanging of the freely possessed offers and bonds happens. It plays out the part of exchanging of assets from those having surplus wage to those having shortage pay. So the stock trade is assuming the part of a go between or delegate between these two gatherings. Other than this, it gives liquidity to the financial specialists, which implies that speculators can promptly and effortlessly exchange their securities in this market. It expands the financial development by expanding the liquidity of benefits and sharing danger of the speculators [3].

The nature and the condition of a securities exchange is of incredible worry to the administration, financial specialists, and for the most part, all the partners. As a financial organization, securities exchange assumes a noteworthy part of improving the productivity of capital development and designation. Along these lines the general advancement of the economy is an element of how well money markets perform [6].

As mentioned above key important factors in such study which can witness stock price movement, role of sovereign indicator has also crucial significant impact on stock prices anomalies, these perhaps witnesses how a movement of stock prices run along with sovereign drivers likewise in a study found interest rate has negative significant relationship stock indices return (KSE-100), exchange rate has also significant relationship with stock returns (KSE-100), while inflation rate found no significant relationship with stock indices returns [7].

\section{Cement Sector of Pakistan}

Improvement of Cement industry is legitimately seen as a gage for money related development. In 1947, Pakistan had procured 4 bond plants with a total cutoff of 0.5 million tons. Some augmentation happened in 1956-66 yet couldn't keep pace with the fiscal change and the country expected to fall back on imports of bond in 1976-77 and continued doing in that capacity till 1994-95. The business was privatized in 1990 which provoked setting up of new plants. Despite the way that an oligopoly publicizes, there exists wild contention between people from the cartel today. 


\begin{tabular}{clllll}
\hline S.no & Independent Variable & \multicolumn{1}{c}{ Dependent Variable } & Relationship & \multicolumn{1}{c}{ Status } & Appropriate Model \\
\hline 1 & Debt - Equity & Earnings per Share & Negative & Not Significant & Random Effect \\
2 & Debt - Equity & Net Profit Margin & Negative & Not Significant & Random Effect \\
3 & Debt - Equity & Return on Capital Employed & Negative & Not Significant & Random Effect \\
4 & Debt - Equity & Return on Equity & Negative & Significant & Fixed effect \\
\hline
\end{tabular}

Hence numerous studies have been conducted to visualized firm performance by keeping fundamental factors in control, therefore most of robust factor that probably Debt to Equity, Gross Profit Margin, Earning Per Share, Return on Capital Employed, Net Profit Margin and so on, jointly conducted research to study behavioral of these few of key performance indicators, Study was comprised on ten random companies from cement sector in the regime of from 2011 to 2018, their findings reveal pretty well understanding for investors that what mentioned in below table [8]

\section{LITERATURE REVIEW}

Securities exchange is a place where optional exchanging of the freely possessed offers and bonds happens. It plays out the part of exchanging of assets from these having surplus wage to those having shortfall wage, so the stock market is assuming part of a mediator or goes amid these two gatherings, Specialized determinants are the large scale financial factors like Inflation rate in a country, State Bank control on money Supply, Government Monetary Policy for interest rate, a country's GDP Growth, market hype, currency fluctuation, war and climate, exchange rates, industrial production, political occasions, natural disaster and demand and supply and so forth are considerable monetary pointers which can influence Share Price [3].

A considerable measure of research was conducted on the factors and prime mover that impact share prices, the crux of the research may consist on Fundamental analysis, Technical analysis or Investor's behavior (Behavioral Finance). These determinants of share price was started for the developed market likewise US, Europe and others, further it also recognized Dividend Payout, Net Profit Margins (NPM) and Book Value per Share (BVPS) as the conspicuous variables impacting share price in the developed markets, that point onward, a significant assemblage of observational, theoretical and hypothetical and writing has developed that witnessed factors of market price of shares [2].

\section{Earing Per Share (EPS) Impacting Share price}

Share prices react to EPS under distinctive level of development rate of operating revenue. The observational outcome demonstrated that association amid Share prices and EPS are existed over the long haul. Moreover, they found that for the firm with an abnormal state of development rate, EPS has less power in clarifying the Share prices in any case, for the firm with a low level of development rate; EPS has a solid impact in Share prices [9].

Using linear regression model the results show that entities' book Value, acquiring per share has a noteworthy positive association with company's Share price of the company's stock [10].

Several determinants impacting share price, entity specific determinant, for instant, earning per share has a considerable agreed intention with firm's market price [11].

Via utilizing information of oil and gas and concrete segment of Karachi Stock Exchange (KSE) over the time of 2008 to 2013, Earning per share has a positive and critical determinant of share price in Oil and Gas and Cement parts [12].

Profit per share has been considered to derive its impact on market cost of offers in the specific market. The results demonstrate that the determinant has critical determinants of share prices in the Bahrain advertise. A high R2 (0.80) uncovered under both the connected models additionally records the huge impact of this determinant available cost of offers. This suggests financial specialists can settle on ideal venture choices and be guaranteed reasonable returns on the off chance that they consider this determinant, EPS, which has advanced to be the huge supporter of the market cost of offers in Bahrain [1].

Ten assembling entities' four year information (2009-2012) was gone up against arbitrary examining strategy for this review. Association and relapse are utilized to discover the impact of gaining per share on share price. An investigated result there is solid positive connection amid Earning per offer and share price. Additionally procuring per offer can clarify $89.7 \%$ on share price of ten dummy producing entities in Sri Lanka [13].

An attempt is made in this paper to concentrate the impact of Earnings per share (EPS) available estimation of a value share in the Indian setting. The review depends on information of 50 entities over a time of 5 years. The 50 entities that have been chosen are the initial 50 entities in the rundown of India's most significant entities according to the Business Today Survey of 2010. In view of our examination, we reason that EPS impacts the market estimation of a value share in the Indian setting [14]. 
In this examination discovering, it can be reasoned that there is a solid positive association amid Public Bank Berhad's EPS on its Share price and that there is a critical impact of gaining declaration on Public Bank Berhard's Share price [15].

This study takes ups the example of Earning per share (EPS) varies from Milanka Companies in Colombo Stock Exchange (CSE) firms in Sri Lanka over the time of five year that is from 2006 to 2010. Exact results demonstrate, so the Earning per share changes impacts share costs, however such results just somewhat bolster the theory. In this review, over seventy percent of Milanka entities have positive connection amid gaining per offer and offer value developments. In this examination, $44 \%$ of share price of Milanka entities is dictated via different determinants without the EPS. In general, this gives prove that the Milanka Companies consider the acquiring per offer of different entities, with a specific end goal to stay with the picture and consumer loyalty. Outer contenders additionally ought to consider the specific firms' EPS points of interest to contending in the market adequately [16].

A case of nineteen Kuwaiti affiliations \& revealed earning per share as a determinant of share prices in Kuwait [17].

In another study, researchers took an instance of seven Kuwaiti banks to aggregate information amidst the period from 1980 to 2004 and revealed book value per share and Earning per Share as prime mover of share price [18].

Sharma and Singh [19], used data from hundred and sixty Indian firms in the region of 2001 and 2005 and found that benefit per share, Value wage extent are the determinants of offer expenses. In 2009, Somoye study the Nigeria stock exchange and found Earning per share as determinants of offer expenses.

In another research of Sharma, which was conducted in 2011, India's firms data from the period 1993to 2009 was examine and concluded that Earning per share impact positively on the offer expenses.

A research conducted in Pakistan, in which two hundred \& twenty-one Pakistani firm's data from the period of 1995 to2006 was used and found firm size and Earning per share as prime mover of Share price [20].

\section{Dividend per Share (DPS) Impacting Share price}

A specimen of (seventy-three) 73 organization has been selected from Pakistan Stock Exchange (KSE) recorded (KSE-100) firms between 2003-2008 and asymmetrical impact models are connected on the board information. The results found that profit tactic is association with the stock value unpredictability at
Pakistan Stock Exchange. The result reveal that steady with the previous analysts of forming economies that value is fluctuate which is hard to predict might be declined while using an impact corporate profit strategy [21].

An example of three hundred \& thirty-three USA firms recorded on Stock Exchange of New York (NYSE), for a time of 3 years from 2009 to 2011 was chosen. The review connected co-social and un-tested inquiry about the idea. The general discoveries of this review demonstrate that profit per share clarify the fluctuation of value share prices in America. The review isolated assembling firms from administration industry firms and found that comparative factors clarify the offer value change. This review adds to the writing on the factors that clarify fluctuation of value share prices [22].

A research was done on Bangladesh's stock Exchange, a selection was made from non-Islamic Banks, listed in stock exchange, reliable and valid results were obtained. To explain the chemistry amid share price and dividend per share, Panel data approach was used while controlling the determinants like Earnings per Share, Return on Equity, Retention Ratio have positive relation with Share prices and significantly explain the variations in the market prices of shares, while the Dividend Yield and Profit after Tax has negative, inappropriate relation with share prices. The conclusion of this study shows that Dividend policy is main mover of Share price [23].

Firm factor to be specific profit per share has been examined to derive their impact on market cost of offers in the specific market. The results show that the determinant profit per offer is huge determinants of share prices in the Bahrain advertise. A high R2 (0.80) uncovered under both the connected models additionally reports the noteworthy impact of this factors available cost of offers [1].

The review utilizes board information relating to thirty firms containing BSE SENSEX over the period 2010-2014 and utilizes the completely adjusted common slightest squares technique. The results demonstrate that the factors uses taken after via PriceEarnings Ratio, Profitability and DPS separately are the significant determinants of share prices in Indian securities exchange. The converse association of Leverage with the share prices demonstrates that raising capital via means of obligation includes intermittent premium installments on some portion of firms; expanded utilization of obligation via a firm would along these lines result in higher premium installments and this brings down the profit accessible to value shareholders. Financial specialists in this manner for the most part lean toward firms with lower obligation [24]. 
Test from American banks utilized and found that profit per offer and book Value per share impact share costs. An examination from 1977-1983 demonstrates that profit for every offer and firm size are the determinants of share prices [2].

An example of Pakistani entities amid 19812000 from Karachi Stock Exchange were utilized and revealed payout proportion, firm size, and profit yields as determinants of share prices [25].

Budgetary Explantions of 29 Listed Companies incorporated via Nepal Stock Exchange Ltd. for the period 1991-1999 and revealed profit for every offer as a determinant of share prices [26].

From hundred \& sixty Indian firms in the vicinity of 2001 and 2005 were utilized and found that profit per share, value income proportion, profit per share, profit scope, profit payout, book Value per offer, and firm size are the determinants of share prices [19].

Information was gathered from India over the time of 2000-2009 and revealed profit for each offer and value income proportion as the critical determinants of share prices [27].

\section{Book Value per Share Impacting Share price}

Several determinants impacting stock value, entity specific determinant, for instant, company's book Value has a generous positive implication with firm $\mathrm{s}$ showcase cost [11].

An instant of three hundred \& thirty-three USA firms recorded on Stock Exchange of New York (NYSE), for a time of 3 years from 2009 to 2011 was chosen. The review connected co-social and un-tested inquiry about the idea. The general discoveries of this review demonstrate that Book Value per offer of the firm clarify the change of value share prices in America. The review isolated assembling corporations from administration sector firms and get that comparative determinant clarify the offer value difference. The review adds to the writing on the determinant that clarifies change of value share prices [22].

Utilizing direct relapse demonstrate the results show that entities' book Value having a noteworthy positive association with association's Share price while profit yield is having a huge backwards association with the market cost of the company's stock [10].

Via utilizing information of oil and gas and concrete part of Karachi Stock Exchange (KSE) over the time of 2008 to 2013, book Value per offer is sure and huge determinant of share price in Oil and Gas and Cement segments [12].
Firm specific factors to be specific book Value per share have been considered to construe their impact on market cost of offers in the individual market. The results show that the determinant book Value per offer is critical determinant of share prices in the Bahrain advertise. A high R2 (0.80) uncovered under both the connected models additionally records the noteworthy impact of this determinant available cost of offers. This suggests financial specialists can settle on ideal speculation choices and be guaranteed reasonable returns on the off chance that they consider this determinant which has developed to be the critical supporters of the market cost of offers in Bahrain [1].

In a study ofone of Arab country, Kuwait, seven banks were considered to gather information amid period from 1980 to 2004 and revealed Book Value per share as determinants of Share price.

Sharma [28] utilized information from Indian's firm for the period from 1993 to 2009 and found that Book Value per share decidedly impact on the Share price.

\section{Gross Domestic Product (GDP) Impacting Share price}

The Share prices and future GDP development are connected. He gave two unmistakable clarifications for this; the primary clarification was that adjustments in data about the future course of GDP make costs change in money markets today. He likewise said that adjustments in Share prices, regardless of what the source is, will lessen firms' benefit positions and influence the cost of their obtaining. When it costs more for firms to obtain cash, they get and contribute less, GDP development moderates. Changes in data about the future course of GDP may make costs change in the share trading system. This clarification proposes that while Share prices are utilized to anticipate future financial action, the real causality is from future GDP development in current Share prices [29].

In the course of recent decades, capital markets in creating nations have encountered a quick advancement. The offer market is ceaselessly moving and changing and it is influenced not just via the achievement of the recorded entities, additionally via the dynamic business condition. Share costs are extremely unstable and continue changing due to a few reasons, both unsurprising and erratic. The learning of how open money related data makes Share prices change is in this manner of imperative significance for the stock trade advertise players remembering that present future financial specialists more often than not Value the share price of an entity. The master construes that GDP would incite augment in securities trade execution. Research suggests that any monetary authority who ever needs to put via obtaining or offering shares in money markets; he should almost screen the GDP execution to choose if it's plausible to 
contribute then. Budgetary pros should buy shares when GDP is performing insufficiently and offer when the GDP performs well for them to have essential endeavors [30].

\section{Interest Rate Impacting Share price}

Initially, if a speculator considers financing cost as cost of capital, an expansion or a lessening in loan fee may influence the venture choice of the speculators. For instance, when there is an ascent in loan cost and the open door cost goes up, individual financial specialists would like to put resources into non-settled salary securities, for instant, bonds [31]. This may come about either in benefit or misfortune which is reflected in the company's monetary record. At the point when the benefit or loss of a firm is promptly reported the Share price of a firm will increment or lessening. This implies that the valuation of a firm would either increment or reduction its Share price thus stock returns. The level of financing costs impacts monetary action through the capital venture handle. Low financing costs energize capital uses via people and entities. These uses give extra business, expanded yield of merchandise and ventures, and general increments in GDP. Loan fees have been firmly connected with monetary action since they intently move with the business cycle. As needs be, the recommendation is that it ought to contrarily correspond stock returns. 91-day Treasury bill is utilized as intermediary for loan fee since Treasury charge fills in as the open door fetched for of holding offers [6].

The connection amid the loan fee affectability of regular stock returns and the development structure of the association's ostensible contracts was inspected in 1984. Utilizing a specimen of impactively exchanged business banks and stock investment funds and advance affiliations, basic stock returns are observed to be associated with loan fee changes. The co-development of stock returns and financing cost changes is emphatically identified with the extent of the development contrast amid the company's ostensible resources and liabilities [32].

In the event that an entity obtains liquidity to extend and develop the organization, if the cost of loan is higher it will affect the cost of its compulsion. It can be reason to declining in the profit margin of the shareholders. Subsequently, it might be the reason of decline in the share price. A decrease in intrigue and growth rate brought about expanded Share prices; expanded DGP has a positive impact. Government ought to subsequently execute strategies that will lessen swelling rate and enhance the way of life of its subjects.
The loan cost ought to be made direct in order to support venture and exchanges in stock [29].

\section{RESEARCH METHODOLOGY Research Design Research Strategy}

By nature this piece of paper is type of secondary research, hence to conduct such research archival data was required, which actually was achieved from various available sources in Pakistan, one of the most authentic sources is Pakistan Stock Exchange and Annual Report of each sampled company.

\section{Choice}

Being type of secondary research which much more depends on quantitative side, than mono method was the only option best fitted in this research.

\section{Time Horizon}

The research employed panel data set, which is driven from different authentic sources, mostly articles written on stock performance within Pakistan, therefore doing such mass working, research took around half of a year to present sound findings.

\section{Population}

There are 19 Companies in Cement Sector which are listed in Pakistan Stock Exchange.

\section{Sample Size}

Out of 19 companies in cement sector, we have taken 16 companies, because we could not find data for rest of the companies and data time regime consist from 2007 to 2016.

\section{Technique and Procedures}

Most of the research have been conducted on somehow same topic but having different time zone and different countries, therefore this study is consider as empirical study, to conduct this study data was only available on the official website of Pakistan Stock Exchange from where we took share prices and dividend history rest of data was achieved from annual report of each sampled company.

Eviews version 10 was employed for equation modeling, below are the detail of models specification and other details.

- Panel Data was employed

- Descriptive Statistic

- Correlation

- Data Stationarity (Unit Root)

- Multiple Regression Model

- Hausmen Test (Random Effect / Fixed Effect) 


\section{Definition and Calculation of Variables}

\begin{tabular}{|c|c|c|c|c|}
\hline S.no & Variable Name & Type & Definition & Formulae \\
\hline 1 & Earnings Per Share & Independent & $\begin{array}{l}\text { Earnings per share is the monetary value of earnings per outstanding share of common stock } \\
\text { for a company. }\end{array}$ & $\begin{array}{l}\text { EPS }=\text { Total Earnings } / \text { Outstanding } \\
\text { Shares }\end{array}$ \\
\hline 2 & Dividend per Share & Independent & $\begin{array}{l}\text { Dividend per share (DPS) is the sum of declared dividends issued by a company for every } \\
\text { ordinary share outstanding. The figure is calculated by dividing the total dividends paid out } \\
\text { by a business, including interim dividends, over a period of time by the number of } \\
\text { outstanding ordinary shares issued. }\end{array}$ & $\begin{array}{l}\text { Dividend per Share }=\text { Total Dividends } \\
\quad \text { Paid / Outstanding Shares }\end{array}$ \\
\hline 3 & Book Value per Share & Independent & $\begin{array}{l}\text { The book value of assets and shares are the value of these items in a company's financial } \\
\text { records.The book value per share is a market value ratio that weighs stockholders' equity } \\
\text { against shares outstanding. In other words, the value of all shares divided by the number of } \\
\text { shares issued. }\end{array}$ & $\begin{array}{l}\text { Book Value Per Share }=(\text { Total } \\
\text { Common Shareholders Equity - Prefered } \\
\text { Stock }) \text { / Outstanding Shares }\end{array}$ \\
\hline 4 & Gross Domestic Produc & Control & $\begin{array}{l}\text { Gross domestic product is a monetary measure of the market value of all the final goods and } \\
\text { services produced in a specific time period. }\end{array}$ & $\begin{array}{l}\text { GDP }=\text { Consupmtion }+ \text { Investment }+ \\
\text { Government Spendings }+ \text { (Exports - } \\
\text { Imports) }\end{array}$ \\
\hline 5 & Interest & Control & $\begin{array}{l}\text { The proportion of a loan that is charged as interest to the borrower, typically expressed as } \\
\text { an annual percentage of the loan outstanding. }\end{array}$ & KIBOR Rate \\
\hline 6 & Stock Price & Dependent & $\begin{array}{l}\text { A share price is the price of a single share of a number of saleable stocks of a company, } \\
\text { derivative or other financial asset. In layman's terms, the stock price is the highest amount } \\
\text { someone is willing to pay for the stock, or the lowest amount that it can be bought for. }\end{array}$ & Absolute Price (Not Divident Adjusted) \\
\hline
\end{tabular}

\section{Conceptual Framework}

\section{After The Careful Study}

The Following Conceptual Model is figured to outline the connection amid ward determinant, for instant, EPS, DPS and Book Value and autonomous factors to be specific Share price of Textile Sector of Pakistan.

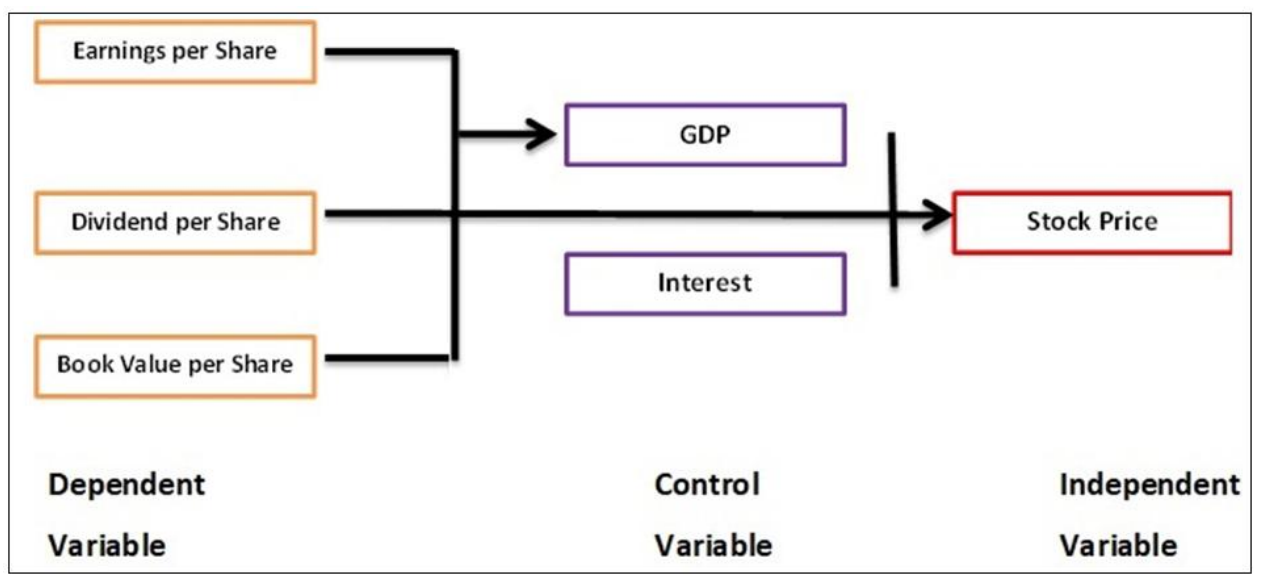




\section{Hypothesis}

Following hypothesis were tested for the accomplishment of the research objectives.

\begin{tabular}{ll}
\hline Hypothesis & \multicolumn{1}{c}{ Descriptions } \\
\hline $\mathbf{H}_{0}$ & Earnings per Share does not have any Significant Impact on Stock Prices \\
$\mathbf{H}_{1}$ & Earnings per Share has any Significant Impact on Stock Prices \\
\hline $\mathbf{H}_{0}$ & Dividend per Share does not have any Significant Impact on Stock Prices \\
$\mathbf{H}_{2}$ & Dividend per Share has any Significant Impact on Stock Prices \\
\hline $\mathbf{H}_{0}$ & Book Value per Share does not have any Significant Impact on Stock Prices \\
$\mathbf{H}_{3}$ & Book Value per Share has any Significant Impact on Stock Prices \\
$\mathbf{H}_{0}$ & Gross Domestic Product does not have any Significant Impact on Stock Prices \\
$\mathbf{H}_{4}$ & Gross Domestic Product has any Significant Impact on Stock Prices \\
\hline $\mathbf{H}_{0}$ & Interest Rate does not have any Significant Impact on Stock Prices \\
$\mathbf{H}_{5}$ & Interest Rate does not have any Significant Impact on Stock Prices \\
\hline
\end{tabular}

Model specification

$\mathrm{S} . \mathrm{P}=\beta 0+\beta 1 . \mathrm{DPS}+\beta 2 . \mathrm{BPS}+\beta 3 . \mathrm{EPS}+$
$\beta 4 . \mathrm{GDP}+\beta 5 . \mathrm{I}+\mathrm{e}$

Where,

S.P $=$ Stock Price
DPS = Dividend per Share
BPS $=$ Book Value per Share
EPS = Earnings per Share
GDP = Gross Domestic Product
$I=$ Interest Rate
$\beta 0=$ Constant
$\beta 1=$ Slope
$\beta 2=$ Slope
$\beta 3=$ Slope
$\beta 4=$ Slope

$$
\beta 5=\text { Slope }
$$$$
\mathrm{e}=\text { Error }
$$

\section{DATA RESULT AND ANALYSIS}

The entire crux of the study would be covered in this section, initially pre-requisite test are employed to encounter the soundness of the constructed models, pre-requisite mainly are Auto-Correlation, Multicolinearity, Stationarity and parameter significant test, therefore a statistical software has been employed to performed entire operations, going forward to test model appropriateness Hausemen-Test was use whether if random or fixed effect model fits well in our modeling.

\section{RESULT DISCUSSION Univariate Analysis}

\begin{tabular}{|l|l|l|l|l|l|l|}
\hline & \multicolumn{6}{|l|}{ Descriptive Statistics } \\
\hline & BVPS & DPS & EPS & GDP & IR & Stock Price \\
\hline Mean & 37.69 & 2.40 & 4.97 & 3.71 & 9.84 & 48.07 \\
\hline Median & 23.20 & 0.00 & 1.31 & 3.95 & 9.25 & 19.08 \\
\hline St.Dev & 38.51 & 8.09 & 9.38 & 1.41 & 2.99 & 81.71 \\
\hline Max. & 214.37 & 96.00 & 40.03 & 6.18 & 14.50 & 631.42 \\
\hline Min. & 23.85 & 0.00 & -18.79 & 1.61 & 4.40 & 19.07 \\
\hline Skewness & 1.78 & 9.83 & 1.34 & -0.02 & -0.21 & 4.19 \\
\hline Kurtosis & 6.85 & 113.20 & 5.17 & 1.96 & 2.23 & 25.36 \\
\hline Observation & 160 & 160 & 160 & 160 & 160 & 160 \\
\hline
\end{tabular}

Aforementioned table witnessed the structure of the population; univariate analysis witnesses few of the core concepts of individual estimator e.g. the preferable central tendency measure witness that average of Book Value Per Share (BVPS) of taken sample is around 37.69 Rupees however keeping in view the most preferred tendency measure refers us the average of the BVPS is around 23.200, herewith the accurate measure encounters outlier as well, DPS is almost none in taken data frame. EPS is seen around 1.31 rupees on average, move over average growth rate approximately $3.95 \%$ annually. Interest rate remains stagnate $9.25 \%$ in each year on an average basis, and last not least average of stock prices for taken data frame is around 19.07 Pakistani Rupees.

Standard deviation is one of the measures to witness volatility in the data set; hence the highest volatility is recorded in stock price around 81.71 , which is generally understandable because in Pakistan stock market remains quite unpredicted. Pakistan is counted in underdeveloped countries, country develops if GDP 
records significantly on upward trend, but unlikely these phenomena here in above mentioned table the least volatile segment is GDP rate which is again quite understandable as per the grounded theories.

The highest price of a stock was captured around 631.42 in the taken sample size and vice versa the lowest was sold on 19.07 Pakistani rupees. One of the most essential assumptions in multiple regressions model is data normality which genuinely witnessed through Skewness and Kurtosis. These two test encounter data dispersion in bale curve, therefore prescribed benchmark for these measure is 3.75 (plus minus), keeping these benchmarks DPS was found more dispersed in nature and rest of them are quite better and normally distributed. Coming towards Kurtosis which mainly showcased higher values in nature, therefore again DPS again found more undistributed segment in the data set hence to keep them normal we are to apply certain (Unit Root Test) test to make data capable to meet basic requirements of regression model. Below are these test which encountered normality of the data.

\section{Data Unit Root}

\begin{tabular}{|l|l|l|l|}
\hline \multicolumn{4}{|l|}{ Augmented Dickey Fuller Test } \\
\hline Variables & t-value & p-value & Unit Root \\
\hline BVPS & -6.6 & 0.0074 & $1^{\text {st }}$ Difference \\
\hline DPS & -28.26 & 0.0000 & Level \\
\hline EPS & -12.52 & 0.0000 & $1^{\text {st }}$ Difference \\
\hline GDP & -28.59 & 0.0000 & $2^{\text {nd }}$ Difference \\
\hline IR & -2.37 & 0.0000 & $1^{\text {st }}$ Difference \\
\hline Stock Price & -2.43 & 0.0000 & Level \\
\hline
\end{tabular}

There are numerous tests which can be used to make the data stationary, hence in this research Augmented-Dickey Fuller test was employed to make stationary. In above mentioned table BVPS, EPS and IR was found unit root at $1^{\text {st }}$ difference whereas DPS and Stock Prices was on Level which means no need to use any lagged for normality, Going forward the most difficult variable which was lastly made stationary is GDP that stood at $2^{\text {nd }}$ difference hence the $p$-value below 0.05 proclaimed data stationary. After the lengthy process data made quite smooth and used in the regression model.

Model Specification (Fixed Effect - Random Effect)
Hausman Test - Fixed-Random Effect Model
\begin{tabular}{|l|l|l|l|}
\hline Test Summary & Chi-Square & Chi-Sq d.f & Probability \\
\hline Cross Section Random Effect & 7.26 & 3 & 0.0641 \\
\hline
\end{tabular}

Hausman Test the most common technique to making decision whether model is best fit in fixed effect specification or random effect specification. Hausmen Test Null Hypotheis: Random Effect model Is fit for the model and vice versa Alternative Hypotheses: suggests that Fixed Effect model Is best fit for the regression model.
As in above mentioned table p-value is greater than 0.05 which means we can't reject null hypothesis and the chi-square equation direct us to go with random effect model which must the best fit with regression model, going forward research secures results driven from the random effect model that can be further described in next section.

\section{RESULTS AND DISCUSSION}

\begin{tabular}{|l|l|l|l|l|}
\hline Variables & Coefficients & Std.Error & t-statistic & Prob. \\
\hline BVPS & 49.44 & 11.04 & 4.47 & 0.000 \\
\hline DPS & 0.98 & 0.68 & 1.42 & 0.156 \\
\hline EPS & 11.48 & 6.42 & 1.78 & 0.000 \\
\hline GDP & 22.09 & 6.46 & 3.41 & 0.000 \\
\hline IR & -7.32 & 3.31 & -2.21 & 0.040 \\
\hline C & -284.68 & 64.89 & -4.38 & 0.000 \\
\hline & R-Square & 0.774 & F-Square & 68.580 \\
\hline & DW Stats. & 1.998 & Prob. & 0.000 \\
\hline
\end{tabular}

Finally here research comes with the results, as mentioned in the above table results seems much more interesting. As general, many investor believes that dividend per share surely impact stock prices of an 
entity, but unfortunately in cement sector it is invert, there is no significant impact on dividend per share on stock prices, hence can be possible if specifically firms in cement sector believe in wealth maximization that reflects in rise in stock prices on compound annual basis, Indeed research indicates this assumptions as above discussed the most volatile segment was stock prices as discussed in descriptive tables.

DPS only variable found no association to stock price.

Book value per share was found the most effecting variable of stock price, coefficient indicates positive heavy impact on stock prices, however $\mathrm{p}$-value is less than 0.05 which means alternative hypothesis cannot be rejected and records positive significant impact on stock prices, whereas coefficient says 49.44 unit change in dependent variable. In general, this segment witnessed soundness/goodness of retained earnings, firms having positive net worth or magnificently on higher side would be having more Book Value per share, in the light of above statement for wealth maximization, firms in cement sector eager to retain profit instead of distributing to the shareholders, therefore retained earnings in cement sector stagnate largely on positive side, that ultimately reflects significant impact of Book Value per share on stock prices, more specifically as much higher the Book Value per share as much higher the prices of the stock because any stock can't be sold less than its book value, moreover it has also been observed that BVPS have considerable unit change effect on stock price that what was determined by coefficient of equations.

Earnings per Share mostly a considerable variable in stock equation modeling, hence in the light of above driven equation, EPS placing significant positive association with stock prices, hence this is so general the higher the EPS the more will be the stock prices, stock having more EPS are tend to have much more demand by the investor, and the rule of thumb if demand increases than supply will decrease hence ultimately records significant change in stock prices on upward side or in opposite case vice versa. These observations again witnessing the role of wealth maximization in cement sector.

Macroeconomic indicator plays pivotal role in growth of stock market, has few of the fat economic indicator likes wise Gross Domestic Product, Interest Rate, Inflation Rate, Exchange Rate and Foreign Direct Investment. In this study we have encounter GDP and Interest Rate as Controlled Variable.

Gross Domestic Product have significant positive impact of stock prices in cement sector, therefore Pakistan is considered as under developed country where lots of construction work all over the Pakistan is being done which is becoming cause of more cement production in Pakistan that reflects in balance sheet of each sample company in this study, moreover the most well know project which is under construction is One Belt One Road or China Pakistan Economic Corridor (CPEC), hence rapid increase in production of cement places significant contribution in GDP of Pakistan and the whole idea is when GDP increases stock price of cement sector will also increase in parallel.

The higher the risk the higher the return should, coming with concept an investor who is willing to invest into stock market requires return according to its risk appetite, so this idea speaks that the returns should be more than interest rate. If an investor is ready to take risk than he tend to have more return compare to risk free investment, to encounter this philosophy we have taken interest rate as controlled variable. Most similar to [7] interest rate has significant negative impact of stock prices, this witnesses whenever interest rate goes up investor moves to risk free investment because there is less risk rather than stock market investment. More generally, when interest rate goes up stock price goes down because it has significant negative relationship.

Below is the decision table for hypothesis.

\begin{tabular}{|l|l|l|}
\hline Hypothesis & Descriptions & Decision \\
\hline $\mathbf{H}_{\mathbf{0}}$ & Earnings per Share does not have any Significant Impact on Stock Prices & Reject \\
\hline $\mathbf{H}_{\mathbf{1}}$ & Earnings per Share has any Significant Impact on Stock Prices & Do not Reject \\
\hline $\mathbf{H}_{\mathbf{0}}$ & Dividend per Share does not have any Significant Impact on Stock Prices & Do not Reject \\
\hline $\mathbf{H}_{\mathbf{2}}$ & Dividend per Share has any Significant Impact on Stock Prices & Reject \\
\hline $\mathbf{H}_{\mathbf{0}}$ & Book Value per Share does not have any Significant Impact on Stock Prices & Reject \\
\hline $\mathbf{H}_{\mathbf{3}}$ & Book Value per Share has any Significant Impact on Stock Prices & Do not Reject \\
\hline $\mathbf{H}_{\mathbf{0}}$ & Gross Domestic Product does not have any Significant Impact on Stock Prices & Reject \\
\hline $\mathbf{H}_{\mathbf{4}}$ & Gross Domestic Product has any Significant Impact on Stock Prices & Do not Reject \\
\hline $\mathbf{H}_{\mathbf{0}}$ & Interest Rate does not have any Significant Impact on Stock Prices & Reject \\
\hline $\mathbf{H}_{5}$ & Interest Rate does not have any Significant Impact on Stock Prices & Do not Reject \\
\hline
\end{tabular}

Last not least after the section of hypothesis justification main crux of the study still remaining that witnesses the soundness of the model, as given in regression table, the coefficient of determination (R-
Square) is significantly on the higher side which lies at $77.40 \%$, meaning $77.40 \%$ dependent variable is explained by independent variable and rest of 22.60 is stood as unexplained variation in the model, that might 
some other variables which may contribute rest of the variation in the model and unfortunately were not explore in this study.

Analysis of variance or F-Statistic p-value in above table is less than 0.05 which means that the model is fit; ANOVA is the representative of model fitness. Moving forward, the last assumption of the regression model that there should be any serial correlation or time segment correlation amongst the data set, which is determine by the value of durbin Watson, in above table value of Durbin Watson is around 2 which means there no autocorrelation in the model and model is fit to use.

\section{CONCLUSION}

The core findings reveals that, there are robust drivers which actually driving stock prices in cement sectors, hence the model represents significant impact of Book Value per Share and Earning Per Share. Investors do consider any stock which is having healthy BVPS and EPS as mentioned above these stocks are demanded more and have significantly high stock prices. Moving forward Dividend Per Share was testing in the model and hence found no significant affiliation with stock price in cement industry, therefore the concept was driven from the equation in cement sector firms tend to retain the profit and go for the profit maximization approach to establish stock price of their entity. While covering there crucial segment sovereign indicators were also tested by keep them in variable equation, therefore robust considerable results have been driven which proclaims the soundness and pivotal role of their presence. Sovereign indicators were probably Gross Domestic Product and Interest rate. GDP was found significant positively associated with stock prices which indicates that as much construction work is done within in the country as much it will contribute in economic growth hence production will be generated by cement industry, it also witnesses the role of cement export because globally Pakistan is considered as strong player in cement export, finally GDP grows so stock prices of cement sector will grow. Keeping GDP as fat indicator in our study, we can't ignore the pivotal role of interest rate or policy rate. Most of investor who goes for stock market investment always consider interest rate as benchmark, investor tend to have more return rather than interest rate, therefore this have be found that as much interest rate goes up as much stock price will fall due to negative relationship and this trend has also been observed in Pakistan stock market, he shift of investment from stock market to risk free securities.

Significant of this study, it will help investor to understand DPS, EPS and BVPS importance in cement sector, their decision making can be supported by this piece of study. In future research any researcher may expand sample size and variable to precede this research further.

\section{REFERENCES}

1. Sharif, T., Purohit, H., \& Pillai, R. (2015). Analysis of Factors Affecting Share Prices: The Case of Bahrain Stock Exchange. International Journal of Economics and Finance, 7(3), 207.

2. Collins, S. (1957). Coloured minorities in Britain: studies in British race relations based on African, West Indian, and Asiatic immigrants. Lutterworth Press.

3. Atiq, M., \& Rafiq, M. (2010). Roohullah.(2010). Factors Affecting Stock Prices: A Case Study of Karachi Stock Exchange (KSE). B\&Er, 2 (1), 7 12.

4. Hasher, L., \& Zacks, R. T. (1979). Automatic and effortful processes in memory. Journal of experimental psychology: General, 108(3), 356.

5. Besley, T. (2006). Principled agents?: The political economy of good government. Oxford University Press on Demand.

6. Prempeh, K. B., \& Nsiah Asare, E. (2016). The Effect of Debt Policy on Firms Performance: Empirical Evidence from Listed Manufacturing Companies on The Ghana Stock Exchange.

7. Alvi, J., Rehan, M., \& Khatri, S. (2019). Role of Sovereign Indicators in Performance of Stock Market of Pakistan. Journal of Finance and Economics, 7(2):52-61.

8. Rehan, M., Alvi, J., \& Khatri, S. (2019). The Role of Capital Structure on Firm's Profitability of Listed Cement Sector in Pakistan Stock Exchange.

9. Chang, H. L., Chen, Y. S., Su, C. W., \& Chang, Y. W. (2008). The relationship between stock price and EPS: Evidence based on Taiwan panel data. Economics Bulletin, 3(30), 1-12.

10. Anderson, J. M., Nidhi, K., Stanley, K. D., Sorensen, P., Samaras, C., \& Oluwatola, O. A. (2014). Autonomous vehicle technology: A guide for policymakers. Rand Corporation.

11. Geetha, E., \& Swaaminathan, M. (2015). Study on the factors influencing stock price A Comparative study of Automobile and Information Technology Industries stocks in India. International Journal of Current Research and Academic Review, 3(3).

12. Arslan Iqbal, F. A., Shahid, S., Zaidi, Z., \& Raza, H. Cement Sector of Karachi Stock Exchange (A Panel Data Approach).

13. Tharshiga, P., \& Anandasayanan, S. (2013). Impact of Leverage on Corporate Profitability: A Study on Listed Financial Sector in Sri Lanka. Available at SSRN 2849683.

14. Pushpa Bhatt, P., \& Sumangala, J. (2012). Impact of Earnings per share on Market Value of an equity share: An Empirical study in Indian Capital Market. Journal of Finance, Accounting \& Management, 3(2).

15. Seetharaman, A., \& Raj, J. R. (2011). An empirical study on the impact of earnings per share on stock prices of a listed bank in Malaysia. 
The International Journal of Applied Economics and Finance, 5(2), 114-126.

16. Velnampy, T., \& Pratheepkanth, P. (2011). Does capital structure cause high firm value. Evidence from selected companies in Colombo stock exchange Sri Lanka, In business and Technology.

17. Midani, M. A. (1991). Determinants of Kuwaiti stock prices: An empirical investigation of industrial services, and food company shares.

18. Al-Omar, H., \& Al-Mutairi, A. (2008). Bankspecific determinants of profitability: The case of Kuwait. Journal of Economic and Administrative Sciences, 24(2), 20-34.

19. Sharma, R. R., \& Singh, R. (2006). Pruning intensity modifies canopy microclimate, and influences sex ratio, malformation incidence and development of fruited panicles in 'Amrapali'mango (Mangifera indica L.). Scientia horticulturae, 109(2), 118-122.

20. Nisa, M., Hameed, S., Zehra, S., \& Nishat, A. (2012, January). Correlational Study of Perceived Quality of Home Environment and Self-Concept Among Adolescents. In RSS (p. 54).

21. Nazir, M. S., Nawaz, M. M., Anwar, W., \& Ahmed, F. (2010). Determinants of stock price volatility in karachi stock exchange: The mediating role of corporate dividend policy. International Research Journal of Finance and Economics, 55(55), 100-107.

22. Gill, A., Biger, N., \& Mathur, N. (2012). Determinants of equity share prices: Evidence from American firms. International Research Journal of Finance and Economics, 90(90), 176192.

23. Masum, A. (2014). Dividend policy and its impact on stock price-A study on commercial banks listed in Dhaka stock exchange. Global Disclosure of Economics and Business, 3(1).

24. Pandya, H. B., \& Marvadi, C. R. (2016). Determinants of share prices in India: A study of BSE Sensex. ZENITH International Journal of Business Economics \& Management Research, 6(4), 1-7.

25. Irfan, C. M., Nishat, M., \& Sharif, H. (2002). Key Fundamental Factors and Long-run Price Changes in an Emerging Market-A Case Study of Karachi Stock Exchange (KSE)[with Comments]. The Pakistan Development Review, 517-533.

26. Pradhan, S. (2002). Semantic location. HP.

27. Sanju, P. S., Nirmala, P. S., \& Ramachandran, M. (2011). Are dividend and investment decisions separable?. Applied Economics, 21(20):1515-1524.

28. Sarma, S. D., Adam, S., Hwang, E. H., \& Rossi, E. (2011). Electronic transport in two-dimensional graphene. Reviews of modern physics, 83(2), 407.

29. Reddy, D. L. (2012). Impact of inflation and GDP on stock market returns in India. International journal of advanced research in management and social sciences, 1(6).

30. Ogutu, C. O. (2011). The Relationship Between The Gdp And Share Price Movement At The Nairobi Stocks Exchange.

31. Adam, A. M., \& Tweneboah, G. (2008). Do macroeconomic variables play any role in the stock market movement in Ghana?. Available at SSRN 1152970.

32. Flannery, M. J., \& James, C. M. (1984). The effect of interest rate changes on the common stock returns of financial institutions. The Journal of Finance, 39(4), 1141-1153. 